\title{
The formation of neuromuscular synapses
}

\author{
Steven J. Burden ${ }^{1}$ \\ Molecular N eurobiology Program, Skirball Institute, N ew York University M edical Center, \\ N ew York, N ew York 10016 USA
}

The formation of synapses requires a series of steps including the generation of neurons and their target cells, the guidance of axons to their targets, and the induction of a specialized presynaptic terminal and postsynaptic membrane. This review is primarily concerned with the inductive events that lead to postsynaptic differentiation. Because this phase of synapse formation begins only after motor neurons have navigated to their target muscle cells, the first section of this review summarizes our current understanding of the principles that govern the guidance of motor axons to skeletal muscle cells. The second section will review our current knowledge of signaling molecules and mechanisms that are critical for inducing postsynaptic differentiation. Although the principles and mechanisms of synapse formation are likely to besimilar in the PN S and the CNS, much of our understanding about the mechanisms of synapse formation arises from studies of the vertebrate neuromuscular synapse.

\section{Motor axons project along a stereotyped pathway from spinal cord to muscle}

Much of the evidence for accurate and stereotyped pathfinding arises from studies of the developing chick embryo (Landmesser 1992). The growth cones of chick motor neurons, which are destined to innervate the limb, exit the spinal cord, extend across the rostral half of developing somites, and converge upon a plexus where they intermingle with growth cones that are destined to innervate different muscles. Recent studies suggest that T-cadherin (Fredette et al. 1996), collagen IX (Ring et al . 1996), and the Eph family ligands, HtkL/Lerk2 (Wang and Anderson 1997), which are each expressed preferentially in the caudal half of the somite, repel these motor axons from the caudal half somite and guide them across the rostral somite. Furthermore, because HtkL/Lerk2 (Wang and A nderson 1997), as well as collapsin-1 (Shepherd et al. 1996), are expressed in the dermatome, repulsive signals acting in three dimensions may guide motor axons toward the plexus.

In the plexus the growth cones begin to sort and to associate with growth cones of axons that will innervate the same target, indicating that signals for sorting and pathfinding are associated with cellular and/or extracel-

1E-MAIL burden@satum.med.nyu.edu; FAX (212) 263-8214. lular structures in the plexus (Lance-Jones and Landmesser 1981). After motor axons leave the plexus, they project to either the ventral or dorsal premuscle mass in the limb and ultimately to the appropriate individual muscle (Landmesser 1978). The projection of motor axons to muscle appears to be accurate from the outset, and there are few pathfinding errors that are eliminated by editing (Landmesser 1992).

The idea that motor axons are guided to their appropriate targets by navigational clues presented on the pathway is supported further by experiments in which motor neurons and/or their targets are displaced by transplantation (Lance-Jones and Landmesser 1980). These studies demonstrate that axons of displaced motor neurons, which arrive at the plexus from an aberrant location, are able to reorient and emerge from the pl exus to innervate their appropriate targets. The directional signals are apparently not supplied by muscle, as motor axons project accurately to the appropriate region of the developing limb even in the absence of muscle cells (Lewis et al. 1981). Thus, mesenchymal cells in the plexus region are thought to have an important role in providing clues that guide and direct motor axons to the appropriate region of the developing limb (Lance-Jones and Dias 1991). The navigating signals that these cells may provide to developing motor neurons are not known, but recent studies indicate that hepatocyte growth factor is expressed in the sclerotome and the limb mesenchyme and can guide motor axons in vitro (Ebens et al. 1996).

\section{Guidance clues are provided by cells present on the pathway}

Precedent for the idea that guidance information can be provided by cells situated along a pathway comes from studies in grasshoppers, where developing neurons, termed guidepost cells, have a critical role in directing sensory neurons to their appropriate targets in the CNS (Bentl ey and Caudy 1983). In vertebrates, floor plate cells appear to serve a similar function for the axons of spinal commisural neurons (Colamarino and Tessier-Lavigne 1995b). These specialized glial-like cells in the extreme ventral region of the neural tube synthesize and secrete netrin, a protein that stimulates and orients the growth of commisural axons that extend from the dorsal spinal cord to the floor plate and across the midline. Although 
netrin does not guide the axons of spinal cord motor neurons, netrin can act as a repellent for trochlear motor neurons (C olamarino and T essier-Lavigne 1995a) and for Caenorhabditis el egans motor neurons (Hedgecock et al. 1990). The axons of spinal motor neurons may nevertheless be guided by factors expressed in the floor plate, as the floor plate does contain an activity(s) that is repulsive for devel oping motor axons (Guthrie and Pini 1995).

\section{Axons defasciculate as they tum toward their targets}

Axons associate, or fasciculate, with one another at certain points during pathfinding and diverge from one another as they grow to distinct targets. Thus, mechanisms that control fasciculation and defasciculation are likely to be highly regulated and to have important consequences for accurate pathfinding (Goodman 1996). Consistent with this idea, mutation of certain receptor tyrosine phosphatases (RTPs) in Drosophila results in poor defasciculation and an inability of motor axons to branch and readily locate appropriate muscles (Desai et al. 1996; Goodman 1996; Krueger et al. 1996). Thus, signaling through receptor tyrosine kinases (RTKs) (Elkins et al. 1990; Callahan et al . 1995) and RTPs is likely to regulate adhesion between motor axons. Laminin, $\mathrm{N}$-cadherin, NCAM, polysialic acid, and fibronectin can promote or retard axon growth and have a role in fasciculation. $\mathrm{N} \mathrm{ev}$ ertheless, these adhesi on molecules alone may not have a role in directing different axons to particular pathways. Thus, it is possible that RTKs and RTPs control fasciculation and steering by regulating the strength of adhesion between axons or between axons and substrates.

\section{Motor neurons projecting to different muscles express different homeodomain proteins}

Because different motor axons must decipher and respond differently to navigational clues, motor neurons are presumed to be distinct from one another. Recent studies demonstrate that motor neurons can be distinguished from one another by expressi on of a unique combination of LIM homeodomain proteins (Tsuchida et al. 1994; Tanabe and Jessell 1996). For example, motor neurons that are positioned in the medial ventral spinal cord project to ventral limb muscle and express Isl-1 and IsI-2, whereas motor neurons that are positioned in the lateral ventral spinal cord project to dorsal limb muscle and express Lim-1 and Isl-2 but not Lim-2. Moreover, motor neurons projecting to axial muscle express Isl-1, Isl-2, and Lim-3. Thus, it would not be surprising to find that the subpopulations of motor neurons, distinguished by their combination of LIM homeodomain proteins, also express different cell surface proteins that have a role in guiding motor neuron growth cones to their appropriate target.

\section{Muscle cells may provide pathfinding clues to motor axons once they approach their target}

A first step in accurate pathfinding is to direct motor axons toward their target, and this is likely to be achieved by providing navigational clues along growth pathways and by regulating fasciculation as described above. Once motor axons approach their target, however, additional directional clues are likely to be required, as motor axons must ul timately choose among many target muscles. Motor axons enter the dorsal or ventral region of the developing limb before muscles have individualized; shortly after individual muscles begin to form, axons branch from the main limb nerves and grow toward their appropriate muscle (Landmesser 1992). Because motor axons in muscle-less limbs enter the appropriate dorsal or ventral region of the limb and form primary but not secondary branches (Lewis et al. 1981), muscle cells may have a role in directing motor axons toward the appropriate muscle once the axons are within striking distance of their target.

Studies in Drosophila have identified molecules expressed by muscle cells that are important for target selection. Fasciclin III is a cell surface protein expressed by a subset of motor neurons and their target muscle cells. Fasciclin III-expressing motor neurons normally innervate only fasciclin III-expressing muscle cells but will innervate inappropriate muscle cells that have been forced to express fasciclin III (Chiba et al. 1995). Other adhesive molecules, such as fasciclin II (Lin and Goodman 1994) and connectin (N ose et al. 1992), as well as repulsive molecules, such as the semaphorins ( $M$ atthes et al. 1995), may have similar roles in regulating target sel ection (Tessier-Lavigne and Goodman 1996).

\section{Schwann cells may have a role in synapse formation}

Current ideas about pathfinding suggest that the growth cones decipher guidance signals. Studies of regenerating synapses, however, indicate that Schwann cells have an important role in reinnervation and may guide regenerating motor axons to original synaptic sites (Son and Thompson 1995). Thus, al though Schwann cells lag behind the growth cones of motor axons during development, making it unlikely that they would have a primary guidance role, they do not lag far behind motor neuron growth cones and could have a role in stabilizing or maintaining newly formed synapses (see bel ow).

\section{The neuromuscular synapse is favorable for studying synapse formation}

Shortly after contact between a growing motor axon and a differentiating myotube is established, signals are exchanged between nerve and muscle that initiate the formation and assembly of a highly differentiated presynaptic nerve terminal and a highly special ized postsynaptic apparatus (Dennis 1981; Hall and Sanes 1993; Jennings and Burden 1993). Muscle differentiation and synapse formation occur concomitantly during development. In vertebrates, motor neurons do not prefer or select a predetermined site on the developing myotube; rather, it appears that synapses can form on most if not all of the myotube surface. Although functional synapses form within minutes to hours after contact between de- 
veloping motor nerves and myotubes (Fischbach 1973; Anderson and Cohen 1977), mature and fully differentiated synapses are not evident, at least in mammal s, until several weeks after the first contacts are made. The formation of a mature synapse requires further arborization of nerve terminals, withdrawal and editing of synaptic connections, an increase in the efficiency of acetylcholine rel ease, and additional modifications of the postsynaptic membrane.

A mature skeletal muscle fiber, a syncitial cell containing several hundred to several thousand nuclei, will ultimately be innervated by a single motor axon that terminates and arborizes over $\sim 0.1 \%$ of the muscle $\mathrm{fi}$ ber's cell surface. The neurotransmitter receptors, acetylcholine receptors (AChRs), are localized to this small patch of the muscle fiber membrane, and their localization to synaptic sites during development is a hallmark of the inductive events of synapse formation. Although other proteins are likewise concentrated at synaptic sites, much of our knowledge about the si gnaling mechanisms responsible for synaptic differentiation have come from studies aimed at understanding how AChRs accumulate at synaptic sites.

The neuromuscular synapse is a particularly favorable synapse for studying synapse formation: (1) the synapse is geometrically simple; (2) developing and regenerating synapses can be experimentally manipulated in vivo with relative ease; (3) synapses between motor neurons and muscle cells can be studied in cell culture; (4) synaptic proteins can be readily purified from Torpedo electric organ, an abundant and homogeneous source of neuromuscular-like synapses; and (5) gene expression can be altered and studied in detail in transgenic and mutant mice. Consequently, we have a good understanding of how the neuromuscular synapse is built and an incomplete but growing understanding of the critical genes involved in synaptogenesis.

\section{Substructural organization of the neuromuscular synapse}

The precise organization of molecules in pre- and postsynaptic membranes belies the idea that the neuromuscular synapse is a simple synapse. Rather, the substructure of pre and postsynaptic membranes suggests that complex mechanisms are required to assemble the synapse and to coordinate pre and postsynaptic differentiation.

N erve terminal s are situated in shallow depressions of the muscle cell membrane, which is invaginated further into deep and regular folds, termed postjunctional folds (Fig. 1). AChRs and additional proteins are localized to the crests of these postjunctional folds, whereas other proteins, including sodium channels, are enriched in the troughs of the postjunctional folds (Hall and Sanes 1993). The mechanisms that lead to this spatial segregation of proteins within the postsynaptic membrane are not known. Clustering of AChRs in the postsynaptic membrane, however, is critical for synaptic function, as a high density of synaptic AChRs is required to generate a syn-
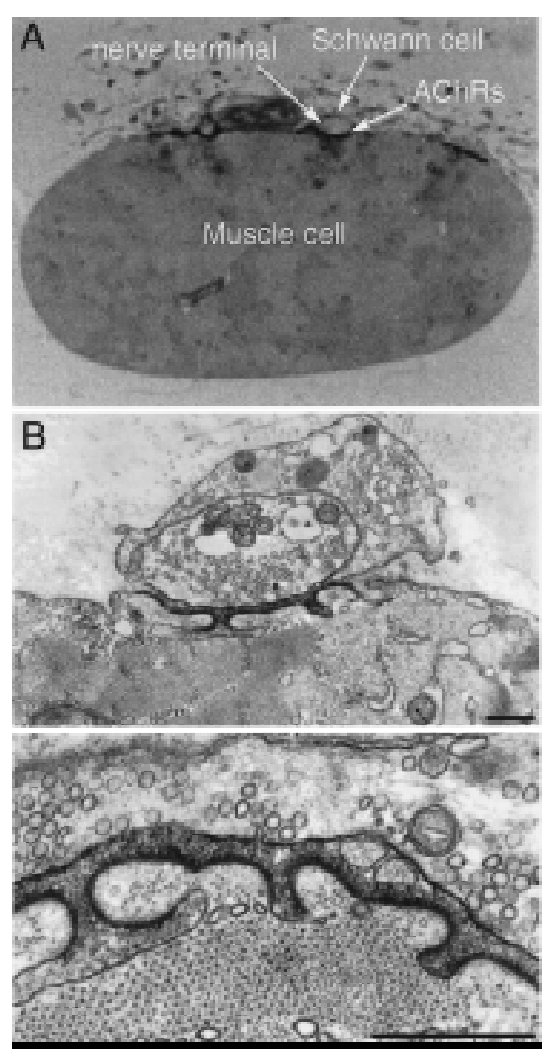

Figure 1. Presynaptic and postsynaptic membranes are highly specialized at neuromuscular synapses. (A) A light microscopic view of a cross section of a muscle fiber shows that nerve terminals, which are capped by Schwann cells, are situated in shallow depressions of an adult muscle fiber. AChRs, stained with horseradish peroxidase-labeled $\alpha$-bungarotoxin (HRP- $\alpha$-BGT), are highly concentrated in the muscle membrane at synaptic sites. (B) An electron microscopic view of a neuromuscular synapse shows that synaptic vesicles are abundant in the region of the nerve terminal facing the muscle fiber, where they are clustered adjacent to active zones. Active zones are organized at regular intervals and are aligned precisely with the mouths of the postjunctional folds in the muscle fiber. AChRs, stained with HRP- $\alpha-B G T$, appear as a dense band at the tops and along the sides of the postjunctional folds; the stain that fills the synaptic cl eft is a result of diffusion of the reaction product from the postsynaptic membrane ( $B$, modified from Burden et al. 1979, with permission of The Rockefeller University Press). Bars, $0.5 \mu \mathrm{m}$.

aptic potential of sufficient magnitude to initiate an action potential in the myofiber.

The nerveterminal is likewise spatially organized, and its substructural organization reflects that of the postsynaptic membrane (Fig. 1) (Hall and Sanes 1993). Synaptic vesicles are abundant in the region of the nerve terminal facing the muscle fiber, where they are clustered adjacent to poorly characterized specializations of the presynaptic membrane, termed active zones, which are the sites of synaptic vesicle fusion. Active zones are organized at regular intervals and are aligned precisely with the mouths of the postjunctional folds. This precise registration of active zones and postjunctional folds ensures that acetylchol ine encounters a high concentration 
of AChRs within microseconds after release, thereby facilitating synaptic transmission. This alignment of structural specializations in pre- and postsynaptic membranes, separated by a 50-nm synaptic cleft, indicates that spatially restricted signaling between pre- and postsynaptic cells is important to coordinate pre and postsynaptic differentiation.

\section{The synaptic basal lamina contains signals for synaptic differentiation}

Two signaling molecules that regulate postsynaptic differentiation at developing and adult neuromuscular synapses are located in the synaptic basal Iamina (Jennings and Burden 1993). The idea that the synaptic basal Iamina contains an activity that stimulates postsynaptic differentiation originated from studies of synaptic differentiation in developing (Anderson and Cohen 1977) and regenerating muscle (Burden et al. 1979; McMahan 1990). These studies demonstrated that motor neurons cause a redistribution of previously unlocalized AChRs to synaptic sites and that a signal (s) for AChR clustering is contained in the synaptic basal lamina. Although there is evidence that the synaptic basal Iamina al so contains signals that direct presynaptic differentiation (Sanes et al. 1978), it has been difficult to establish a simple and reliable cell culture assay for identifying and purifying signals that regulate presynaptic differentiation. Thus, we know little about the nature of the signals for presynaptic differentiation. The following section will summarize our current understanding of the signaling mechanisms that lead to differentiation of the postsynaptic membrane.

\section{Agrin induces postsynaptic differentiation}

Because clustering of AChRs can be readily studied in cell culture, it was possible to devise a straightforward assay for identifying signals that induce this aspect of postsynaptic differentiation. Although several factors can induce clustering of A ChRs in cultured muscle cells, the evidence that the relevant signals are located in the synaptic basal lamina provided important insight that allowed for purification of the appropriate in vivo activity. McMahan and colleagues found that extracellular matrix from Torpedo electric organ, a tissue that is homologous to skeletal muscle but more densely innervated, contains an activity that stimulates AChR clustering in cultured myotubes and that this activity, like the signal at developing neuromuscular synapses, triggers clustering of AChRs by post-translational mechanisms (Godfrey et al. 1984; N itkin et al. 1987). The electric organ activity was purified and termed agrin (MCMahan 1990). Agrin is a $\sim 200-k D$ protein containing multiple epidermal growth factor (EGF)-like signaling domains, two different laminin-like domains, and multiple follistatin-like repeats. The four EGF-like domains and three laminin-like $\mathrm{G}$ domains are contained in the carboxy-terminal region, which is sufficient for inducing AChR clusters in cultured myotubes; sequences in the amino-terminal region are thought to be responsible for the association of agrin with the extracellular matrix.

Agrin is transported in the axons of motor neurons and released into the synaptic basal lamina, where it is highly concentrated near sites of synaptic vesicle fusion (M. Schwarz, P. Theodosopoulos, R. Marshall, and U.J. M cMahan, unpubl.). Two lines of evidence indicate that agrin is necessary for clustering of AChRs at synaptic sites and for inducing postsynaptic differentiation. First, antibodies against agrin block AChR clustering at nervemuscle synapses that form in cell culture (Reist et al. 1992), and second, mice lacking agrin lack normal synapses (see below) (Gautam et al. 1996). Agrin al so regulates the distribution of other synaptic proteins, including acetylcholinesterase (AChE), rapsyn, utrophin, neuregulin (NRG), and NRG receptors (ErbBs) (see below), indicating that agrin has a central role in synaptic differentiation (M cMahan 1990; A pel et al. 1995; Rimer et al. 1996; M eier et al. 1997).

The agrin gene is expressed in a variety of cell types. Alternative splicing results in multiple agrin isoforms that differ in their AChR clustering efficiency (Ferns et al. 1992, 1993; Ruegg et al. 1992; Hoch et al. 1993). The isoform that appears to be the most active in clustering AChRs is expressed in neurons, whereas other agrin isoforms are expressed in additional cell types, including skel etal muscle cells (Fallon and Gelfman 1989; Ferns et al. 1992; Ruegg et al. 1992). Although agrin has been shown to have a critical role in the formation of neuromuscular synapses, the role of agrin in the CNS and in non-neural cells is currently not known. The active, neuronal-specific isoforms of agrin contain 8 or 19 amino acids at a splice site, referred to as the $Z$ site in rat agrin (Ferns et al. 1992; Hoch et al. 1993) and the B site in chick agrin (Ruegg et al. 1992). A 40-kD carboxy-terminal fragment of agrin, containing two EGF-like domains, two laminin-like $G$ domains, and the B site, clusters AChRs with the same potency as full-length agrin (Hoch et al. 1994), whereas a carboxy-terminal 21-kD fragment, containing a single EGF-like domain, a single lamininlike $\mathrm{G}$ domain, and the $\mathrm{B}$ site, is 200 -fold less active than full-length agrin (Gesemann et al. 1995).

Experiments with chimeric synapses between different frog species indicate that nerve-derived agrin is present at synaptic sites from the earliest stages of synapse formation (Cohen and Godfrey 1992). Furthermore, experiments with chimeric synapses between chick and rat demonstrate that blocking antibodies to nerve-derived but not to muscle-derived agrin inhibit AChR clustering (Reist et al. 1992). Although muscle-derived agrin may have a role in synapse formation, these results demonstrate that muscle-derived agrin cannot substitute for nerve-derived agrin in clustering AChRs, at least in cell culture.

Several lines of evidence, however, indicate that muscle agrin could have a role in synapse formation. First, nerve and muscle agrin, when attached to cells or extracellular matrix, can be similarly active in clustering AChRs (Ferns et al. 1992, 1993). Second, muscle-derived agrin can serve as a stop, or growth-arrest signal, for mo- 
tor axons (C ampagna et al. 1995). Third, muscle-derived agrin can serve as a transcriptional signal that induces expression of AChR genes (Jones et al. 1996). Selective restoration of agrin expression in motor neurons or in skeletal muscle from agrin mutant mice may provide important insight into the potential role of skeletal muscle-derived agrin (Gautam et al. 1996).

\section{MuSK is required for agrin-mediated signaling and synapse formation}

The mechanism of agrin-mediated AChR clustering is not known, but a RTK, termed MuSK, appears to be a critical component of an agrin receptor complex. M USK was discovered using a strategy designed to identify tyrosine kinases, which are abundant in the synapse-rich Torpedo el ectric organ and which might therefore be involved in synaptic differentiation (Jennings et al. 1993). The cytoplasmic domain of M uSK, including sequences outside the tyrosine kinase domain, is similar to that of neurotrophin receptors, whereas the extracellular domain of MuSK, which contains four immunoglobulinlike domains, similar to those in a variety of receptors and adhesion molecules, is divergent from that of the neurotrophin receptors (Jennings et al. 1993). MuSK is highly expressed in Torpedo electric organ and in the skel etal muscle of Torpedo and higher mammals, where it is concentrated in the postsynaptic membrane (Jennings et al. 1993; Valenzuela et al. 1995).

M ice lacking M uSK expression (DeChiara et al. 1996), like agrin mutant mice (Gautam et al. 1996), lack normal neuromuscular synapses. Indeed, the similar phenotype of agrin and MuSK mutant mice is consistent with the idea that M USK is a component of an agrin receptor complex (see below). Both agrin and MuSK mutant mice are immobile, cannot breathe, and die shortly after birth. Muscle differentiation is largely normal in agrin and MuSK mutant mice, but MuSK mutant muscle fibers lack all known features of postsynaptic differentiation. Muscle-derived proteins, including AChRs, AChE, rapsyn, and NRG receptors, which are concentrated at synapses in normal mice, are uniformly distributed in MuSK mutant myofibers. In addition, AChR genes, which are normally transcribed selectively in synaptic nuclei of normal muscle fibers (see bel ow), are transcri bed at si milar rates in synaptic and nonsynaptic nuclei of muscle fibers from agrin and MuSK mutant mice. These studies show that MuSK is required for neuromuscular synapse formation (DeC hiara et al. 1996).

Five lines of evidence indicate that M USK is required for agrin-mediated signaling and is a component of the agrin receptor complex (Glass et al. 1996): (1) Cultured MuSK mutant muscle cells, unlike normal muscle cells, do not cluster AChRs in response to agrin; (2) cultured muscle cells expressing a dominant-negative form of MuSK likewise fail to cluster AChRs in response to agrin; (3) a recombinant, soluble extracellular fragment of MUSK inhibits agrin-induced AChR clustering in cultured muscle cells; (4) agrin induces rapid tyrosine phosphorylation of MuSK; and (5) agrin can be chemically cross-linked to M uSK. M uSK, which has been forceexpressed in cells other than myotubes, however, cannot be activated by agrin, indicating that other activities or additional proteins that are myotube-specific are required for agrin-mediated signaling (Glass et al. 1996, 1997). In principle, the additional myotube-specific activity/activities could be a coreceptor (Jing et al. 1996), a coli gand (Klagsbrun and Baird 1991; Lopez-Casillas 1991; Rapraeger et al. 1991; Ferns et al. 1993; Aviezer et al. 1994), or post-translational modifications (Fig. 2) (Binari et al. 1997).

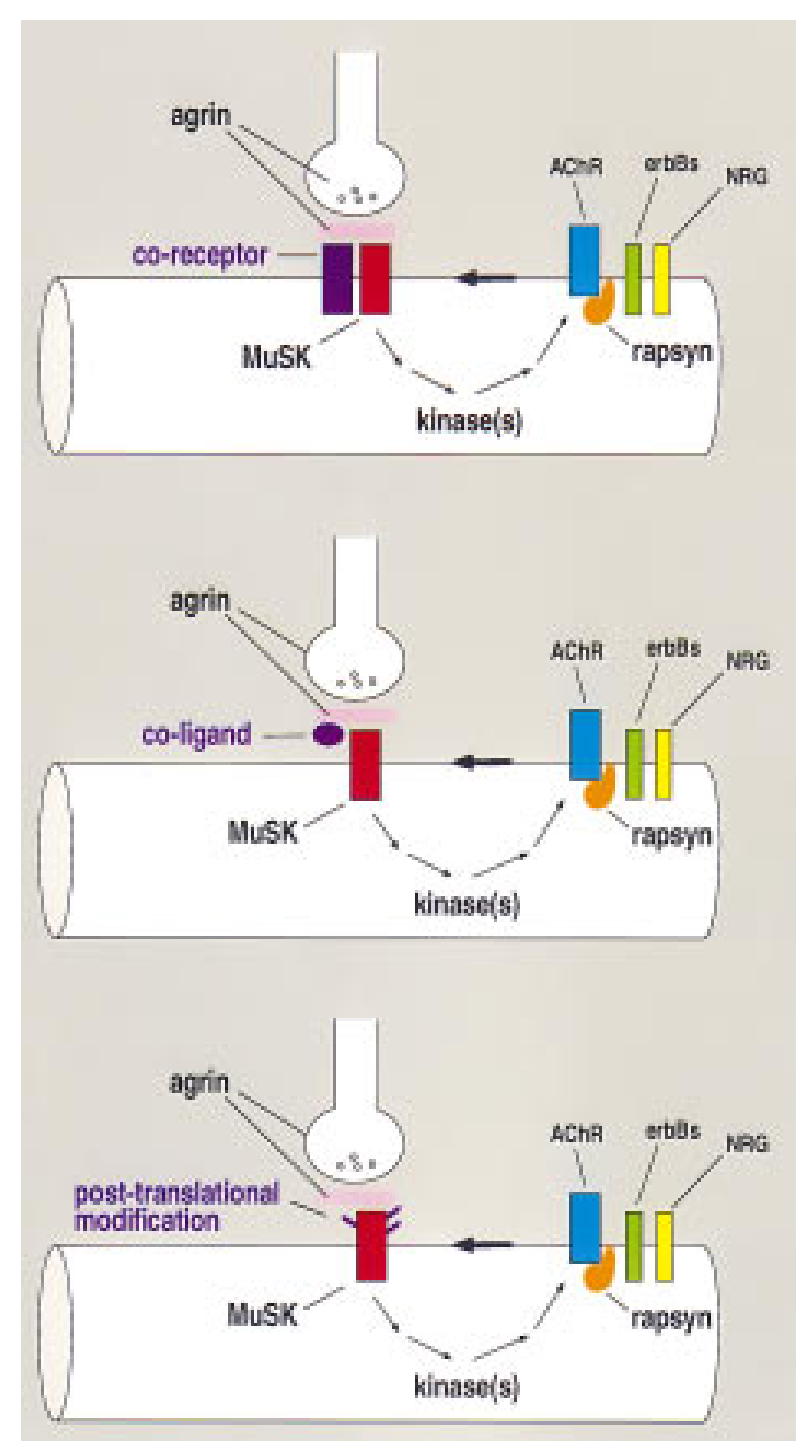

Figure 2. Agrin activation of M USK leads to clustering of synaptic proteins, including AChRs, rapsyn, ErbBs, and musclederived NRG. Current data indicate that a myotube-specific activity/activities is required for agrin to activate MuSK; this activity/activities may be a coreceptor, a coligand, and/or posttranslational modifications. Because staurosporine blocks agrin-stimulated AChR clustering and AChR tyrosine phosphorylation but does not inhibit MuSK tyrosine phosphorylation, a kinase(s) downstream of M USK is important for agrin-mediated signaling; this kinase(s) may or may not be activated by agrin. 
agrin and MuSK mutant mice have similar but distinguishable phenotypes, as AChR clusters are entirely absent in skeletal muscle of MuSK mutant mice, whereas AChR clusters, though infrequent, can be detected in agrin mutant mice. Furthermore, motor axons termi nate and arborize at some of the AChR clusters in agrin mutant mice. These results raise the possibility that a second signal, which is independent of agrin but dependent on M uSK, can initiate postsynaptic differentiation (Gautam et al. 1996). Alternatively, the high level of MuSK expression in muscle that is deprived of functional innervation (Valenzuela et al. 1995) might result in spontaneous dimerization and ligand-independent activation of MuSK, leading to stimulation of downstream signaling.

\section{$\alpha$-Dystroglycan binds agrin}

$\alpha$-Dystroglycan binds agrin (Bowe et al. 1994; Campanelli et al. 1994; Gee et al. 1994; Sugiyama et al. 1994), raising the possibility that dystroglycan collaborates with M uSK to mediate agrin signaling. $\alpha$-Dystroglycan is a peripheral membrane protein that binds laminin in the extracellular matrix and is covalently linked to $\beta$-dystroglycan, an integral membrane protein that associates intracellularly with dystrophin (Ervasti and Campbel 1991) or utrophin (M atsumura et al . 1992), a dystrophinrelated protein that is highly concentrated at nervemuscle synapses (Ohlendieck et al. 1991).

$\mathrm{N}$ evertheless, the role of $\alpha$-dystroglycan as an agrin receptor remains unclear. Although antibodies to $\alpha$-dystroglycan have been reported to perturb the formation of AChR clusters induced by agrin (Campanelli et al. 1994; Gee et al. 1994), others have reported the same antibodies to be ineffective in altering the response to agrin (Sugiyama et al. 1994). Moreover, soluble muscle agrin binds dystroglycan well but neither stimulates nor antagonizes AChR clustering by active, neural agrin (Hoch et al. 1994). In addition, recent studies indicate that the dystroglycan-binding sequences in agrin are not necessary for AChR clustering (Gesemann et al. 1995). Furthermore, because AChRs and rapsyn are clustered normally in mice that lack both dystrophin and utrophin and that have markedly reduced levels of dystroglycan (Deconinck et al. 1997; Grady et al. 1997), it seems unlikely that dystroglycan has a critical role in initiating AChR clustering in response to agrin. It remains possible, however, that dystroglycan is a receptor for laminin at neuromuscular synapses and serves to consolidate clustering of AChRs initiated by agrin (Sugiyama et al. 1997; S. Carbonetto, C. Jacobson, F. Montanaro, M. Lindenbau, and $\mathrm{M}$. Ferns, unpubl.).

\section{Agrin and MuSK are required for retrograde signaling and presynaptic differentiation}

Although pathfinding of motor axons to muscle is normal in mice lacking agrin or MuSK, agrin and MuSK mutant mice lack normal nerve terminals (DeChiara et al. 1996; Gautam et al. 1996). Branches of the main in- tramuscular nerve in the mutant mice neither establish normal contacts with the muscle nor form correctly positioned or specialized nerve terminals. These results suggest that motor axons in agrin and MuSK mutant mice and are not provided with appropriate stop signals, and in the absence of termination signals, axons wander across the muscle surface. Because M uSK is expressed in skel etal muscle and not in motor neurons (Jennings et al. 1993; Valenzuela et al. 1995), it seems likely that the aberrant behavior of presynaptic terminals in MuSK mutant mice is due to indirect actions of agrin/MuSK signaling. These results raise the possibility that agrin released from nerve terminals causes the muscle cell, via MuSK activation, to reciprocally release a recognition signal back to the nerve, or to Schwann cells, to indicate that a functional contact has occurred. In response to this muscle-derived signal, the nerve would stop growing and undergo presynaptic differentiation. Alternatively, the lack of synaptic activity in MuSK mutant mice may result in aberrant retrograde signaling, resulting in exuberant growth of motor axons. In either case, these results demonstrate the importance of the reciprocal signaling relationship between nerve and muscle during development.

\section{Rapsyn is required for postsynaptic differentiation and is downstream of agrin and MuSK}

Although there is little information regarding the signaling pathways that are activated by agrin, a 43-kD protein, termed rapsyn, is known to have an important role in agrin-mediated signaling. Rapsyn is a myristolated, peripheral membrane protein that is present at 1:1 stoichiometry with AChRs at synaptic site and may interact directly with AChRs and potentially other synaptic proteins (Burden et al. 1983; Froehner 1991; Philips and Merlie 1992).

Agrin stimulates clustering of rapsyn in myotubes grown in cell culture, and clustering of rapsyn and AChRs appears to occur coincidentally at developing synapses (Burden 1985; N oakes et al. 1993). We do not know how agrin activation of M uSK leads to clustering of rapsyn and how clustering of rapsyn leads to the aggregation of other synaptic proteins. Rapsyn, however, is critical for synapse formation. Mice lacking rapsyn expression die within hours after birth and have difficulty moving and breathing (Gautam et al . 1995). Importantly, normal clustering of AChRs, NRG receptors, utrophin, and dystroglycan is lacking in rapsyn mutant mice. Other aspects of synaptic differentiation are relatively normal in rapsyn mutant mice: (1) MuSK is local ized to rapsyn mutant synaptic sites, demonstrating that clustering of M uSK at synapses is rapsyn-independent (A pel et al. 1997); (2) AChR gene expression is enriched in the central region of rapsyn mutant muscle; and (3) synaptic basal lamina proteins, AChE and s-laminin, are localized, albeit at lower levels, at mutant synaptic sites. Because basal lamina proteins do not diffuse readily from their site of deposition and because AChE and s-laminin 
are encoded by RN As that are localized to synaptic sites (Jasmin et al. 1993; M oscoso et al . 1995a), the persistence of synapse-specific gene expression in rapsyn mutant mice may explain the localization of AChE and s-laminin proteins at rapsyn mutant synaptic sites.

Forced expression of rapsyn in Xenopus oocytes or in a fibroblast-like cell line, QT6 cells, results in clustering of rapsyn, and clustering of rapsyn is necessary and sufficient to cluster AChRs in these cells (Froehner et al. 1990; Philips et al. 1991). Rapsyn can al so cluster M uSK in QT6 cells that are forced to express both rapsyn and MuSK, indicating that rapsyn and M USK associate either directly or indirectly (Gillespie et al. 1996).

\section{Downstream of MuSK}

The extracellular domain of MUSK appears to have an important role in clustering rapsyn, as mutant or chimeric forms of M uSK that contain only the ectodomain of M uSK can be clustered by rapsyn in QT 6 cel Is (Apel et al. 1997). Because rapsyn is a peripheral membrane protein associated with the cytoplasmic surface of the plasma membrane, these experiments suggest that rapsyn associates with an unknown protein, which is expressed in QT6 cells as well as in muscle cells, that interacts directly or indirectly with the extracellular domain of M uSK. Because M uSK is cl ustered at synapses in rapsyn mutant mice (A pel et al . 1997), these results suggest a model in which matrix-bound agrin engages and clusters MuSK, MuSK clusters an unknown linker protein(s), the linker protein(s) clusters rapsyn, and rapsyn clusters AChRs. This model, however, does not take into account the kinase activity of MuSK, which is required for agrin to stimulate clustering of AChRs (DeChiara et al. 1996; Glass et al. 1997). M oreover, because staurosporine inhibits $A C h R$ clustering without blocking agrinstimulated tyrosine phosphorylation of MuSK (Wallace 1994; Ferns et al. 1996; Fuhrer et al. 1997), there appears to be at least one kinase in addition to MuSK that is necessary for AChR clustering (Fig. 2). Clearly, a better understanding of the agrin-stimulated clustering pathway will require identification of the substrates that are tyrosine phosphorylated by MuSK and are necessary for clustering rapsyn and $\mathrm{AChRs.}$

Models for MuSK-mediated clustering must also be consistent with the stoichiometry of MuSK, rapsyn, and AChRs. Although rapsyn and AChR are present at equal stochiometry at synapses (Burden et al. 1983), MuSK is likely to be present at synapses at substantially lower levels: AChR and rapsyn mRNAs are present at similar levels in Torpedo electric organ, whereas M uSK mRN A is $\sim 60$-fold less abundant than rapsyn or AChR (Jennings et al. 1993). Thus, it seems likely that MuSK regulates clustering of synaptic proteins by serving as a catal yst for assembly rather than by participating as a stochiometric and stable component of a rapsyn/AChR complex.

Much of our current thinking about agrin/MuSK/rapsyn/AChR interactions is predicated on results obtained in QT6 cells. Interpretation from these studies presumes that mechanisms that regulate the distribu- tion of rapsyn, MuSK, and AChRs in transfected QT6 cells resemble that in muscle cells. Because clustering of rapsyn in muscle cells is dependent on agrin and M USK (DeChiara et al. 1996; Gautam et al. 1996), whereas rapsyn clusters "spontaneously" in QT 6 cells (Philips et al. 1991), it appears that QT 6 cells have substituted or bypassed mechanisms used in muscle that require agrin/ MuSK signaling to cluster rapsyn. Consequently, the steps that follow agrin/M uSK signaling and that lead to rapsyn clustering have not been amenable to study in QT6 cells.

Biochemical evidence demonstrating association, direct or indi rect, between M USK and rapsyn either in QT6 cells or muscle cells is currently lacking. Recent studies, however, demonstrate that M USK and AChRs can be coimmunoprecipitated from muscle cells and that agrin stimulation increases the amount of M uSK that is associated with AChRs (Fuhrer et al. 1997). The complex containing MuSK and AChRs is likely to contain additional proteins (see below), and identification of these proteins is likely to provide insight into mechanisms of agrin-induced AChR clustering.

\section{Agrin stimulates tyrosine phosphorylation of AChRs}

Agrin stimulates tyrosine phosphorylation of the AChR $\beta$ - and $\delta$-subunits, and the time course of AChR phosphorylation precedes AChR clustering (Wallace et al. 1991; Qu and Huganir 1994; Ferns et al. 1996). AChR phosphorylation and clustering are relatively slow [AChR tyrosine phosphorylation is detectable by $15 \mathrm{~min}$ after agrin treatment, and AChR clustering is first detectable $\sim 3 \mathrm{hr}$ after agrin treatment (Ferns et al. 1996)], indicating that multiple steps are likely to lie between agrin activation of MuSK and AChR phosphorylation and clustering.

The function of AChR tyrosine phosphorylation is unclear, but it is insufficient to cluster AChRs, as AChR tyrosine phosphorylation but not AChR clustering is stimulated in muscle cells that are transfected with a trkC/M uSK chimera and treated with NT3 (Glass et al. 1997). The kinase that stimulates AChR tyrosine phosphorylation appears to be distinct from MuSK, as staurosporine blocks agrin-stimulated AChR tyrosine phosphorylation without inhibiting MuSK phosphorylation (Fuhrer et al. 1997). These results indicate that M uSK activation is either required to activate the downstream kinase(s) and/or to recruit AChRs into a complex containing an active kinase(s). Although others have suggested that this downstream kinase(s) may be a Src-like kinase, possibly Src and/or Fyn (A pel et al. 1997; Fuhrer et al. 1997), we have found that AChRs are clustered normally at neuromuscular synapses in mice lacking both Src and Fyn (C.L. Smith, E.D. Prescott, and S.J. Burden, unpubl.). Further studies will be required to determine whether Src-like kinases are required for tyrosine phosphorylation of AChRs and whether tyrosine phosphorylation of AChRs is required for clustering AChRs or other aspects of synaptic function. 


\section{Certain genes are expressed selectively in synaptic nuclei of myofibers}

Agrin-mediated signaling results in a reorganization of proteins associated with the muscle cell membrane. A second signaling pathway regulates synaptic differentiation by controlling expression of genes encoding synaptic proteins.

Like AChR protein, the mRNAs encoding the different subunits $(\alpha, \beta, \gamma$ or $\epsilon$, and $\delta)$ of the AChR are concentrated at synaptic sites (M erlie and Sanes 1985; Fontaine and Changeux 1989; Goldman and Staple 1989). Studies with transgenic mice that harbor gene fusions between regulatory regions of $A C h R$ subunit genes and reporter genes have shown that AChR mRN A becomes localized at synaptic sites, at least in part, because AChR subunit genes are transcribed at a higher rate in myofiber nuclei positioned near the synaptic site than in nuclei in nonsynaptic regions of the myofiber (Klarsfeld et al. 1991; Sanes et al. 1991; Simon et al. 1992).

At present, AChR subunits are the only genes known to be selectively transcribed in the synaptic nuclei of skeletal myofibers. RNAs encoding other synaptic proteins, including AChE, MuSK, rapsyn, s-laminin, N$C A M$, utrophin, and the regulatory subunit of protein kinase A, however, are also concentrated at synaptic sites (Jasmin et al. 1993; M oscoso et al. 1995a; Valenzuela et al. 1995; Imaizumi-Scherrer et al. 1996; Gramolini et al. 1997), and these results raise the possibility that these genes are al so transcribed preferential ly in synaptic nuclei. In support of this idea a recent study reports that the utrophin gene is expressed preferentially in synaptic nuclei (Gramolini et al. 1997). Thus, synapse-specific gene expression may be a general and important mechanism for clustering proteins at developing and adult neuromuscular synapses (Burden 1993; Chu et al . 1995b; Duclert and Changeux 1995).

Because proteins at the neuromuscular synapse turn over while the synapse remains stable, si gnaling mechanisms that maintain the appropriate number and distribution of synaptic proteins must function throughout the life of a synapse. Thus, although signaling pathways that regulate cellular differentiation during early development are not often studied in the context of an adult organism, it is not surprising that agrin-mediated signaling and synapse-specific transcription function at adult as well as at developing neuromuscular synapses.

\section{NRG activates AChR gene expression and is concentrated at synaptic sites}

Studies of regenerating muscle have shown that signals for synapse-specific transcription are located in the synaptic basal lamina (Goldman et al. 1991; Brenner et al. 1992; Jo and Burden 1992). Thus, signals in the synaptic basal lamina regulate the structure of the postsynaptic membrane not only by post-translational mechanisms by an agrin-dependent pathway, but also by regulating transcription of genes encoding synaptic proteins.

Several lines of evidence support the idea that NRG, a growth/differentiation factor (see below), may be the basal Iamina signal that activates synapse-specific transcription (Fig. 3). First, NRG activates AChR gene expression in cultured muscle cells, and the N RG response element is contained in the same cis-acting region that confers synapse-specific expression in mice (Gundersen et al. 1993; Tang et al. 1994; Jo et al. 1995; Chu et al. 1995a). Second, NRG is concentrated at synaptic sites (Chu et al . 1995a; Jo et al. 1995; Goodearl et al . 1995), and like the signal that activates synapse-specific gene expression, NRG is present in the synaptic basal lamina (Goodearl et al. 1995; Jo et al. 1995). Third, ErbB3 and ErbB4, two members of the EGF receptor family, are re ceptors for N RG, and both ErbB3 and ErbB4 are concentrated in the postsynaptic membrane at neuromuscular synapses (Alitok et al. 1995; M oscoso et al. 1995b; Zhu et al. 1995).

NRG was initially purified on the basis of its activity as a growth factor stimulating tyrosine phosphorylation of ErbB2 (neu), a member of the EGF receptor family, and was termed NDF (neu differentiation factor) or HRG (he regulin) (Holmes êt al. 1992; Peles et àl. 1992; Wen et al . 1992). Independent studies that led to the purification and cloning of glial growth factor (GGF), a series of Iigands that regulate Schwann cell survival and proliferation (M archionni et al. 1993), and acetylcholine receptorinducing activity (ARIA), a factor that stimulates AChR synthesis in muscle cells (Fal Is et al. 1993), subsequently reveal ed that the NRG/NDF gene encodes GGF and ARIA. Because of their potential contribution to neuronal regulation, as well as their ability to stimulate the phosphorylation of ErbB2 (Neu), the various members of the NDF/HRG/ARIA/GGF family have been dubbed

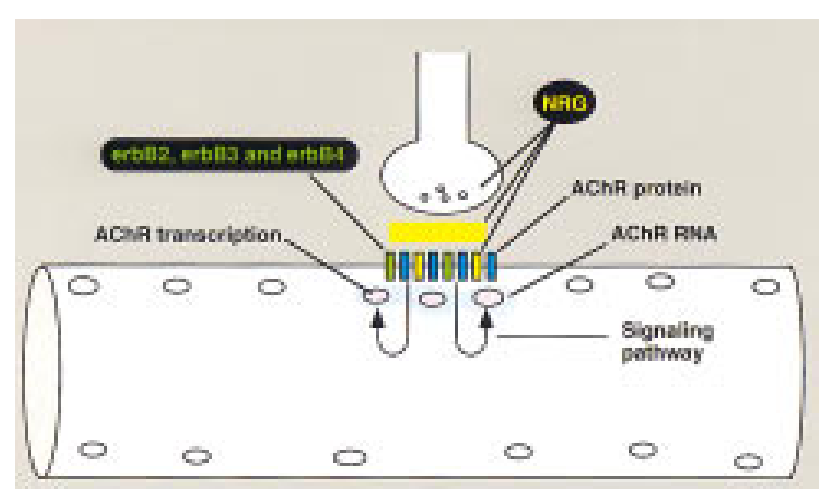

Figure 3. NRG is currently the best candidate for a signal that activates synapse-specific transcription. It is synthesized by motor neurons and muscle fibers and is found associated with the postsynaptic membrane and the synaptic basal lamina. Current evidence suggests that motor neurons synthesize a secreted form of N RG that is rel eased into the synaptic basal lamina and that muscle fibers synthesize a membrane-attached form that is processed to yield a soluble signaling fragment that can associate with the synaptic basal Iamina. Two N RG receptors, ErbB3 and ErbB4, as well as ErbB2, are concentrated in the postsynaptic membrane. Activation of these receptors by N RG is thought to stimulate signaling pathways that activate transcription of certain genes in nuclei positioned near the activated receptors. 
NRGs (Peles and Yarden 1993; Carraway and Burden 1995).

The NRG gene encodes more than one dozen alternatively spliced products. Most NRG isoforms are transmembrane proteins, which may be active on the cell surface or processed, like EGF, to yield a soluble signaling fragment. At least one al ternative splice form has a signal sequence, lacks a transmembrane domain, and is secreted. All NRGs contain a single EGF-like domain, which alone is sufficient for cell signaling. Alternative spicing within the EGF-like domain yields two types of isoforms, $\alpha$ - or $\beta$-type, which differ in their affinity for the different NRG receptors.

The cytoplasmic domain of NRG is significantly longer than the analogous domain in other growth factors (Wen et al. 1992). Moreover, the N RG cytoplasmic sequence is highly conserved in human, rodent, and chicken NRGs. These results raise the possibility that the NRG cytoplasmic domain has an important function, possibly in signaling or in cytoskel etal association.

Alternative splicing results in isoforms containing either an immunoglobulin or cysteine-rich domain. Because NRG isoforms containing the immunoglobulin domain bind heparin (Loeb and Fischbach 1995), secreted and/or processed forms containing the immunogl obul in domain might associate with the extracellular matrix, restricting the growth factor to the cell surface. There is evidence that developing motor neurons first express NRG isoforms containing the cysteine-rich domain and subsequently express both immunoglobulin-containing and cysteine-rich isoforms (Ho et al. 1995; Y. Kuo and L. Role, unpubl.). Thus, it is possible that NRG is a soluble signal at embryonic neuromuscular synapses and becomes localized to the synaptic basal lamina as the synapse matures. Little is known about the role of alternative splicing in other domains of NRG.

It is not known whether NRG or agrin must be associated with the basal Iamina or whether either could function as a membrane-associated or secreted molecule. The precise arrangement of proteins in the postsynaptic membrane of the neuromuscular synapse, however, suggests that it may be important to restrict these signaling molecules to the synaptic site and possibly even to subdomains within the synaptic site, making it less likely that agrin or NRG could function as soluble signaling molecules. Because membrane proteins that are anchored to the cytoskel eton or to the extracellular matrix have limited lateral diffusion, anchored membrane ligands have the potential of providing the required spatially restricted signaling; nevertheless, because a 50-nm synaptic cleft separates nerve terminal and muscle fiber plasma membranes, it is unlikely that signaling proteins attached to the plasma membrane of one cell could extend across the synaptic cl eft to interact with a receptor in the adjacent cell. Because the basal Iamina is situated between nerve and muscle and because molecules in the basal Iamina do not diffuse laterally, molecules in the synaptic basal lamina are particularly well-suited for providing spatially restricted signal ing at neuromuscular synapses.

\section{Autocrine, paracrine, and retrograde signaling}

M otor neurons express N RG, indicating that motor neurons may supply NRG to the synapse (Falls et al. 1993; Marchionni et al. 1993). Consistent with this idea, NRG can be detected in preterminal axons (Jo et al. 1995; Goodearl et al. 1995), and NRG immunostaining at the synapse decreases following denervation (Jo et al. 1995; Moscoso et al. 1995b; Goodearl et al. 1995). Skeletal muscle fibers, however, also express (Moscoso et al. 1995b; M. Rimer, I. Cohen, T. Lomo, S.J. Burden, and U.J. M cMahan, unpubl.) and contribute N RG to the synaptic site (M. Rimer, I. Cohen, T. Lomo, S.J. Burden, and U.J. M cMahan, unpubl.), indicating that N RG may function as an autocrine and/or paracrine signal at neuromuscular synapses (Fig. 3).

\section{Agrin induces NRG and ErbB clustering}

The localization of ErbBs and muscle-derived NRG at synapses suggests that motor neurons provide signals to the muscle to direct ErbB and NRG clustering in the postsynaptic membrane. The mechanisms that direct their clustering at synaptic sites are not known, but re cent studies indicate that agrin has an important role in clustering both muscle-derived N RG and ErbBs (M eier et al. 1997; M. Rimer, I. Cohen, T. Lomo, S.J. Burden, and U.J. McMahan, unpubl.). Injection of an expression vector encoding neural agrin into the nonsynaptic region of adult skeletal muscle results in expression of neural agrin, synthesized by adult myofi bers, at nonsynaptic sites. This ectopic neural agrin induces clustering of AChRs (Cohen et al. 1997; Jones et al. 1997), NRG (M. Rimer, I. Cohen, T. Lomo, S.J. Burden, and U.J. McMahan, unpubl.) and N RG receptors (M eier et al. 1997; M. Rimer, I. Cohen, T. Lomo, S.J. Burden, and U.J. McMahan, unpubl.) at the ectopic agrin sites. These results indicate that agrin is sufficient to induce clustering of musclederived NRG and ErbBs. Taken together with experiments showing that mice lacking agrin or M uSK fail to cluster ErbBs at the synapse (DeChiara et al. 1996; Gautam et al. 1996), agrin-mediated signaling appears to have a critical role in organizing both ligand and receptor components of the N RG signaling system at the synapse.

Interestingly, MuSK mRN A, like AChR mRNA, is localized to synaptic sites (Valenzuela et al. 1995), and these results raise the possibility that the MuSK gene is activated preferentially in synaptic nuclei. If N RG were to activate the MuSK gene in synaptic nuclei, then NRG would control the expression of a component of the agrin receptor, and the two signaling pathways would crossregulate one another. Such convergent signaling would serve to mutually reinforce signaling pathways leading to synaptic differentiation.

\section{Might NRG be a muscle-derived retrograde signal?}

Because muscle cells express and concentrate NRG at synaptic sites, NRG is a candidate for a muscle-derived retrograde signal that could promote the survival of ter- 
minal Schwann cells and indirectly regulate the position of nerve terminals in muscle. Evidence supporting this idea comes from two studies. First, mice that lack ErbB3 fail to develop peripheral Schwann cells and subsequently lose motor and sensory neurons (Riethmacher et al. 1997). As Schwann cells, but not motor neurons, are thought to express ErbB3, these results suggest that Schwann cells are required to maintain motor neurons and that motor and sensory neurons degenerate if Schwann cells are absent. Second, NRG can alter the distribution of Schwann cells and motor axons in skeletal muscle (Trachtenberg and Thompson 1997). Schwann cells within skeletal muscle are normally restricted to intramuscular nerves and to synaptic sites. Injection of NRG into skeletal muscle of newborn rats results in the exuberant growth of motor axons, accompanied by Schwann cells, throughout the muscle. As Schwann cells, but not motor neurons, express NRG receptors, the excessive growth of motor axons is likely due to a direct action of NRG on Schwann cells and an indirect action on motor axons. These results, together with prior studies showing that Schwann cells guide regenerating axons (Son and Thompson 1995), raise the possibility that NRG regulates the position of motor axons by regulating the number and position of Schwann cells in muscle. As neural agrin induces the clustering of muscle-derived NRG (see below), agrin may indirectly stabilize the position of initial contacts between nerve and muscle by clustering N RG at synapses where it can serve as a local, retrograde signal for Schwann cells and indirectly for nerve terminals. The idea that Schwann cells might have an important role in synapse formation clearly requires further consideration.

\section{Mice lacking NRG and its receptors}

N RG is widely expressed in all three germ layers, including mesenchymal and neural tissue, in early development. Importantly, NRG is expressed in the endocardium of the developing heart, and NRG receptors are expressed in the adjacent cardiac muscle. In NRG, erbB2, or erbB4 mutant mice, the trabeculae of the myocardi um fail to form, demonstrating that NRG has an important role in inducing differentiation of cardiac muscle (M eyer and Birchmeier 1995). Because the myocardial trabeculae are critical for maintaining blood flow during the early stages of heart devel opment, mice lacking N RG, ErbB2, or ErbB4 die at embryonic day 10.5 (E10.5) (Gassmann et al. 1995; Lee et al. 1995; Meyer and Birchmeier 1995). Although ErbB2 and ErbB4 are expressed in the same cardiac cells, inactivation of either gene results in a mutant phenotype, and these results demonstrate that ErbB4 cannot function in heart development without ErbB2 and that ErbB2 and ErbB4 are not redundant.

The characterization of erbB3 mutant mice has been reported recently (Riethmacher et al. 1997). A majority of erbB3 mutant mice die between E11.5 and E13.5, possibly owing to a defect in heart development, but $\sim 20 \%$ of erbB3 mutant mice survive until birth. All erbB3 mutant mice lack Schwann cells, consistent with prior stud- ies showing that NRG can regulate survival and proliferation of developing Schwann cells and that ErbB3 is the only NRG receptor expressed in Schwann cells. Importantly, at E15.5 neuromuscular synapses in erbB3 mutant mice appear normal: M otor nerve terminals are positioned normally, and AChRs are clustered. These results indicate that ErbB3 is not required to initiate the first steps in neuromuscular synapse formation. Because both ErbB3 and ErbB4 are concentrated at normal neuromuscular synapses, these results raise the possibility that ErbB4 is sufficient to function as a N RG receptor in the postsynaptic membrane, at least during early stages of synapse formation. In support of this idea, ErbB4 can be detected at neuromuscular synapses prior to ErbB3 (Zhu et al. 1995) (see bel ow).

It remains unclear whether NRG-mediated signaling is required for synapse-specific gene expression, as mice lacking N RG, ErbB2, or ErbB4 die 4 days prior to neuromuscular synapse formation. Recent data, however, support the idea that NRG may have the suspected role at neuromuscular synapses. Adult mice that are heterozygous for the Ig allele of NRG (NRG ${ }^{\mathrm{g}+} \rightarrow$ ) have a mild deficiency in synaptic transmission and fewer (50\%) AChRs at their neuromuscular synapses (Sandrock et al. 1997). The Ig isoform of NRG, however, is not the major NRG isoform in motor neurons, and indeed the spinal cord of $\mathrm{NRG}^{\mathrm{Ig}+\text { - }}$ mice have nearly normal levels of NRG. These results suggest that the immunoglobulinlike domain of NRG may promote accumulation of this isoform in the synaptic basal lamina even at times during development when the abundance of this mRNA is relatively low and/or that muscle fibers, which synthesize largely the Ig isoform of NRG (X. Y ang and S.J. Burden, unpubl.), have an important role in supplying NRG to the synaptic site. Further studies will be required to determine whether NRG-mediated signaling has a role in the formation of neuromuscular synapses and whether synaptic differentiation depends on NRG supplied by motor neurons and/or muscle fibers.

\section{Multiple ErbBs at neuromuscular synapses}

The expression of two NRG receptors together with ErbB2 at synapses raises the possibility that activation of different N RG receptors might regulate different aspects of postsynaptic differentiation. Sequences beyond the tyrosine kinase domain are the major sites for tyrosine phosphorylation and recruitment of downstream signaling molecules in ErbBs, and these sequences are poorly conserved (10\%-30\% identity) among the ErbBs. Thus, there is reason to believe that different ErbBs activate distinct signaling pathways. Consistent with this idea, of the four known EGF receptor family members, only ErbB3 is predicted to couple to the $\mathrm{SH} 2$ domain of $\mathrm{PI}-3$ kinase, and experimental evidence supports this notion. As ErbB3 lacks an intrinsic tyrosine kinase activity and requires hetero-oligomerization with other EGF receptor family members for activation, its role in signaling is apparently to serve as a docking site for signaling proteins that are not recruited to the kinase-active recep- 
tors; this could lead to the stimulation of pathways that cannot be triggered in the absence of ErbB3. Thus, activation of different ErbBs, or different pairwise combinations of ErbBs, could lead to stimulation of different downstream pathways and activation of different celluIar responses (Peles and Yarden 1993; Carraway and Burden 1995).

Interestingly, antibodies to ErbB3 stain synapses weakly in newborn mice, when ErbB4 staining is al ready robust (Zhu et al . 1995); these results raise the possibility that ErbB4 has an early role in postsynaptic differentiation and that ErbB3 has a distinct, later role. In this regard, synaptic expression of the AChR $\alpha, \beta, \gamma$, and $\delta$ subunit genes is evident in mice before birth, whereas the $A C h R \geqq$ subunit gene is not activated until after birth. In addition, other aspects of synaptic maturation, including the formation of postjunctional folds, develop only after birth in mice, rai sing the possiblity of a second wave of synaptic signaling.

Although it is reasonable to suspect that increasing the concentration of ErbBs in the postsynaptic membrane might increase the strength of NRG signaling at the synapse, it is not known whether ErbB clustering is important for synaptic differentiation. It is known, however, that ErbB clustering is not required to localize AChR mRNAs at synaptic sites during early development, as AChR mRN As are local ized at synaptic sites in newborn rapsyn mutant mice that lack clustered ErbBs. These results demonstrate that synapse-specific transcription can be initiated without ErbB clustering and raise the possibility that activation of uniformly distributed ErbBs by neurally supplied NRG is sufficient to selectively activate $A C h R$ genes in synaptic nuclei. Alternatively, signals other than NRG may have a role in initiating synapse-specific transcription (Jones et al. 1996).

\section{Downstream of ErbBs}

ErbB activation is known to lead to activation of Ras (Ben Levy et al. 1994; Marte et al. 1995) and PI-3 kinase (Fedi et al . 1994; Soltoff et al. 1994; Carraway et al. 1995; Gamett et al. 1995) signaling pathways. Although there is agreement that Ras activation is necessary for N RGinduced AChR gene expression (Si et al. 1996; Tansey et al. 1996; Altiok et al. 1997), differing results have been reported for the role of $\mathrm{PI}-3$ kinase in induction of $\mathrm{AChR}$ genes by NRG (Si et al. 1996; Tansey et al. 1996; Altiok et al. 1997).

The sequences in AChR subunit genes that confer synapse-specific gene expression in transgenic mice and NRG responsiveness in cultured muscle cells are contained in $<200$ bp of 5 '-flanking DNA (Gundersen et al. 1993; Tang et al . 1994; Chu et al. 1995a; Jo et al . 1995). A sequence (CCGGAA), termed an N-box, appears to have an important role in conferring synapse-specific expression (Koike et al. 1995; Duclert et al. 1996). Because this sequence conforms to a consensus binding site for Ets proteins, it is possible that Ets proteins have an important role in synapse-specific gene expression.

\section{Conserved mechanisms for synapse formation at the neuromuscular junction and in the CNS}

We know little about the steps and mechanisms that regulate synapse formation in the CNS. The difficulties in studying CN S synapse formation are due to the difficulty of experimentally manipulating developing CNS synapses in vivo, thelack of good cell culture systems for studying synapse formation in vitro, and the absence of an abundant and homogeneous source of CN S synapses. Consequently, we have only scant information about the signaling molecules that might regulate synapse formation in the CNS and a very limited descriptive understanding of how pre- and postsynaptic differentiation are induced and subsequently maintained.

N everthel ess, the structure of CNS and neuromuscular synapses are similar in several important respects, suggesting that similar mechanisms might regul ate their differentiation. For example, active zones are present in the terminals of CN S neurons, and neurotransmitter receptors, such as glycine receptors (Kuhse et al . 1995) and glutamate receptors ( $\mathrm{N}$ omura et al. 1994), are concentrated in the postsynaptic membrane of certain CN S synapses. Although basal lamina is not evident at synapses in the CNS, agrin and NRG are expressed in the CNS, where they may serve as soluble or membrane-associated ligands. A recent study, however, supports the idea that a different class of membrane ligand and receptor, neuroligins and neurexins, may regulate the assembly of proteins in pre and postsynaptic membranes at CNS synapses by binding to PDZ domain-containing proteins and serving as organizing centers for macromolecular complexes (Irie et al. 1997). N evertheless, because rapsyn is expressed in certain neurons (Burns et al. 1997; Yang et al. 1997) and can cluster GABAA receptors in vitro (Yang et al. 1997), agrin may have a role in clustering synaptic proteins in cells that express rapsyn. Two peripheral membrane proteins, gephyrin and the PDZ domain-containing protein PSD-95 (Lahey et al. 1994; Kornau et al. 1995; Kuhse et al. 1995; N iethammer et al. 1996), may serve as functional anal ogs of rapsyn as they copurify with certain neurotransmitter receptors and can regulate the distribution of neurotransmitter receptors and ion channels in vitro. Further insight into the mechanisms of synapse formation in the CN S is likely to benefit from the availability of better cell culture systems and mice carrying targeted mutations in genes thought to have a role in synapse formation.

Despite similarities in the structure of neuromuscular and central synapses, one might expect differences in signaling mechanisms that maintain neuromuscular and CNS synapses. Because the neuromuscular synapse is stable and does not require modulation, it is not surprising that signaling mol ecules responsible for synaptic differentiation are located in the synaptic basal Iamina, where they turn over slowly, that multiple, mutually reinforcing pathways function to cluster synaptic proteins, and that autocrine signaling may have a role in stabilizing postsynaptic differentiation. As current ideas of learning favor the idea that the structure and function 
of certain CN S synapses are altered as a consequence of experience, one might expect that the signaling molecules and mechanisms that regulate synaptic differentiation in the CNS would be better suited for relatively rapid changes in signaling that would ensure flexibility in the function of CNS synapses.

\section{Acknowledgments}

I thank Tom Jessell, Lynn Landmesser, Ruth Lehmann, Gerold Bothe, and Xia Yang for their criticism and comments on the manuscript. Work on neuromuscular synapse formation in my laboratory is supported by grants from the $\mathrm{N}$ ational Institutes of Health (N S27963 and N S21579) and the Muscular Dystrophy Association.

\section{References}

Altiok, N., J.L. Bessereau, and J.P. Changeux. 1995. ErbB3 and ErbB2/neu mediate the effect of heregulin on acetylcholine receptor gene expression in muscle: Differential expression at the endplate. EMBO J. 14: 4258-4566.

Altiok, N., X. Altiok, and J.P. Changeux. 1997. Heregulinstimulated acetylcholine receptor gene expression in muscle: Requirement for MAP kinase and evidence for a parallel inhibitory pathway independent of electrical activity. EMBO J. 16: 717-725.

Anderson, M.J. and M.W. Cohen. 1977. Nerve induced and spontaneous redistribution of acetylcholine receptors on culture muscle cells. J. Physiol. 268: 757-773.

A pel, E.D., S.L. Roberds, K.P. Campbell, and J.P. Merlie. 1995. Rapsyn may function as a link between the acetylcholine receptor and the agrin-binding dystrophin-associated glycoprotein complex. Neuron 15: 115-126.

Apel, E., D. Glass, L. Moscoso, G. Yancopoulos, and J. Sanes. 1997. Rapsyn is required for MuSK signaling and recruits synaptic components to a MuSK-containing scaffold. Neuron 18: 623-635.

A viezer, D., D. Hecht, M. Safran, M. Eisinger, G. David, and A. Yayon. 1994. Perlecan, basal lamina proteoglycan, promotes basic fibroblast growth factor-receptor binding, mitogenesis, and angiogenesis. Cell 79: 1005-1013.

Ben-Levy, R., H.F. Paterson, C.J. M arshall, and Y. Yarden. 1994. A single autophosphorylation site confers oncogenicity to the neu/ErbB-2 receptor and enables coupling to the MAP kinase pathway. EMBO J. 13: 3302-3311.

Bentley, D. and M. Caudy. 1983. Pioneer axons lose directed growth after selective killing of guidepost cells. Nature 304: 62-65.

Binari, R.C., B.E. Stavel ey, W.A. Johnson, R. Godavarti, R. Sasisekharan, and A.S. Manoukian. 1997. Genetic evidence that heparin-like glycosaminoglycans are involved in wingless signaling. Development 124: 2623-2632.

Bowe, M.A., K.A. Deyst, J.D. Deszyk, and J.R. Fallon. 1994 Identification and purification of an agrin receptor from Torpedo postsynaptic membranes: A heteromeric complex related to the dystroglycans. Neuron 12: 1-20.

Brenner, H.R., A. Herczeg, and C.R. Slater. 1992. Synapse-spe cific expression of acetylcholine receptor genes and their products at original synaptic sites in rat soleus muscle fibers regenerating in the absence of innervation. Development 116: $41-53$.

Burden, S.J. 1985. The subsynaptic 43-kDa protein is concentrated at developing nerve-muscle synapses in vitro. Proc. Natl. Acad. Sci. 82: 8270-8273.
-_. 1993. Synapse-specific gene expression. Trends in Gen. 9: $12-16$

Burden, S.J., P.B. Sargent, and U.J. M cM ahan. 1979. A cetylcholine receptors in regenerating muscle accumulate at the original synaptic site in the absence of the nerve. J. Cell Biol. 82: 412-425.

Burden, S.J., R.L. DePalma, and G.S. Gottesman. 1983. Crosslinking of proteins in acetylcholine receptor-rich membranes: Association between the $\beta$-subunit and the 43 kd subsynaptic protein. Cell 35: 687-692.

Burns, A.L., D. Benson, M.J. Howard, and J.F. Margiotta. 1997. Chick ciliary ganglion neurons contain transcripts coding for acetylcholine receptor-associated protein at synapses (rapsyn). J. Neurosci. 17: 5016-5026.

Callahan, C.A., M.G. Muralidhar, S.E. Lundgren, A.L. Scully, and J.B. Thomas. 1995. Control of neuronal pathway selection by a Drosophila receptor protein-tyrosine kinase family member. Nature 376: 171-174.

Campagna, J.A., M.A. Ruegg, and J.L. Bixby. 1995. Agrin is a differentiation-inducing "stop signal" for motorneurons in vitro. Neuron 15: 1365-1374.

Campanelli, J.T., S.L. Roberds, K.P. Campbell, and R.H. Scheller. 1994. A role for dystrophin-associated glycoproteins and utrophin in agrin-induced AChR clustering. Cell 77: 663-674.

Carraway, K.L. III, and S.J. Burden. 1995. Neuregulins and their receptors. Curr. O pin. Neurobiol. 5: 606-612.

Carraway, K.L., S.P. Soltoff, A.J. Diamonti, and L.C. Cantley. 1995. Heregulin stimulates mitogenesis and phosphatidylinositol 3-kinase in mouse fibroblasts transfected with erbB2/neu and erbB3. J. Biol. Chem. 270: 7111-7116.

Chiba, A., P. Snow, H. Keshishian, and Y. Hotta. 1995. Fasciclin III as a synaptic target recognition molecule in Drosophila. Nature 374: 166-168.

Chu, G.C., L.M. Moscoso, M.X. Sliwkowski, and J.P. Merlie. 1995a. Regulation of the acetylcholine receptor $\epsilon$ subunit gene by recombinant ARIA: An in vitro model for transynaptic gene regulation. Neuron 14: 329-339.

Chu, G.C., M.A. Velleca, and J.P. Merlie. 1995b. Synapse-spe cific gene expression. Semin. Dev. Biol. 6: 175-183.

Cohen, I., M. Rimer, T. Lomo, and U.J. M CM ahan.1997. Agrininduced postsynaptic-like apparatus in vivo. Mol. Cell. Neurosci. 9: 237-253.

Cohen, M.W. and E.W. Godfrey. 1992. Early appearance of and neuronal contribution to agrin-like molecules at embryonic frog nerve-muscle synapses formed in culture. J. Neurosci. 12: 2982-2992.

Colamarino, S.A. and M. Tessier-Lavigne. 1995a. The axonal chemoattractant netrin-1 is al so a chemorepellent for trochlear motor axons. Cell 81: 621-629.

- - - 1995b. The role of the floor plate in axon guidance. Annu. Rev. Neurosci. 18: 497-529.

DeChiara, T.M., D.C. Bowen, D.M. Valenzuela, M.V. Simmons, W.T. Poueymirou, S. Thomas, E. Kinetz, D.L. Compton, J.S. Park, C. Smith, P.S. DiStefano, D.J. Glass, S.J. Burden and G.D. Yancopoulos. 1996. The receptor tyrosine kinase, MuSK, is required for neuromuscular junction formation in vivo. Cell 85: 501-512.

Deconinck, A.E., J.A. Rafael, J.J.A. Skinner, S.C. Brown, A.C. Potter, L. Metzinger, D.J. Watt, G. Dickson, J.M. Tinsley, and K.E. Davies. 1997. Utrophin-dystrophin-deficient mice as a model for Duchenne muscular dystrophy. Cell 90: 717727.

Dennis, M.J. 1981. Development of the neuromuscular junction: Inductive interactions between cells. Annu. Rev. Neurosci. 4: 43-68. 
Desai, C.J., J.G. Gindhart, Jr., L.S.Goldstein, and K. Zinn. 1996. Receptor tyrosine phosphatases are required for motor axon guidance in the Drosophila embryo. Cell 84: 599-609.

Duclert, A., and J.P. Changeux. 1995. Acetylcholine receptor gene expression at the developing neuromuscular junction. Physiol. Rev. 75: 339-368.

Duclert, A., N. Savatier, L. Schaeffer, and J.P. Changeux. 1996. Identification of an element crucial for the sub-synaptic expression of the acetylcholine receptor epsilon-subunit gene. J. Biol. Chem. 271: 17433-17438.

Ebens, A., K. Brose, E.D. Leonardo, M.G. Hanson, F. Bladt, C. Birchmeier, B.A. Barres, and M. Tessier-Lavigne. 1996. He patocyte growth factor/scatter factor is an axonal chemoattractant and a neurotrophic factor for spinal motor neurons. Neuron 17: 1157-1172.

Elkins, T., K. Zinn, L. M cAllister, F.M. Hoffmann, and C.S. Goodman. 1990. Genetic analysis of a Drosophila neural cell adhesion molecule: Interaction of fasciclin I and Abelson tyrosine kinase mutations. Cell 60: 565-575.

Ervasti, J. and K. Campbell. 1991. M embrane organization of the dystrophin-glycoprotein complex. Cell 66: 1121-1131.

Fallon, J.R. and C.E. Gelfman. 1989. A grin-rel ated molecules are concentrated at acetylcholine receptor clusters in normal and aneural developing muscle. J. Cell Biol. 108: 1527-1535.

Falls, D.L., K.M. Rosen, G. Corfas, W.S. Lane, and G.D. Fischbach. 1993. ARIA, a protein that stimulates acetylcholine receptor synthesis, is a member of the neu ligand family. Cell 72: 801-815.

Fedi, P., J.H. Pierce, P.P. DiFiore, and M.H. Kraus. 1994. Efficient coupling with phosphatidylinositol 3-kinase, but not phospholipase $\mathrm{C}_{\gamma}$ or GTPase-activating protein, distinguishes erbB3 signaling from that of other erbB/EGFR family members. Mol. Cell Biol. 14: 492-500.

Ferns, M., M. Deiner, and Z.W. Hall. 1996. Agrin-induced acetylcholine receptor clustering in mammalian muscle requires tyrosine phosphorylation. J. Cell Biol. 132: 937-944.

Ferns, M., W. Hoch, J.T. Campanelli, F. Rupp, Z.W. Hall, and R.H. Scheller. 1992. RN A splicing regulates agrin-mediated acetylcholine receptor clustering activity on cultured myotubes. Neuron 8: 1079-1086.

Ferns, M., J.T. Campanelli, W. Hoch, R. Scheller, and Z.W. Hall. 1993. The ability of agrin to cluster AChRs depends on alternative splicing and on cell surface proteoglycans. Neuron 11: 491-502.

Ferns, M., M. Deiner, and Z.W. Hall. 1996. Agrin-induced acetylcholine receptor clustering in mammalian muscle re quires tyrosine phosphorylation. J. Cell Biol. 132: 937-944.

Fischbach, G.D. 1973. Synapse formation between dissociated nerve and muscle cells in low density cultures. Dev. Biol. 38: 407-429.

Fontaine, B., and J.P. Changeux. 1989. Localization of nicotinic acetylchol ine receptor $\alpha$-subunit transcripts during myogenesis and motor endplate development in the chick. J. Cell Biol. 108: 1025-1037.

Fredette, B.J., J. Miller, and B. Ranscht. 1996. Inhibition of motor axon growth by $\mathrm{T}$-cadherin substrata. Development 122: 3163-3171.

Froehner, S.C. 1991. The submembrane machinery for nicotinic acetylcholine receptor clustering. J. Cell Biol. 114: 1-7.

Froehner, S.C., C.W. Luetje, P.B. Scotland, and J. Patrick. 1990. The postsynaptic 43K protein clusters muscle nicotinic acetylchol ine receptors in Xenopus oocytes. Neuron 5: 403-410.

Fuhrer, C., J.E. Sugiyama, R.G. Taylor, and Z.W. Hall. 1997. Association of muscle-specific kinase MuSK with the acetylcholine receptor in mammalian muscle. EMBO J. 16: 4951-4960.
Gamett, D.C., T. Green, A.R. Wagreich, H.H. Kim, J.G. Koland, and R.A. Cerione. 1995. Heregulin-stimulated signaling in rat pheochromocytoma cells-evidence for erbB3 interactions with neu/erbB2 and p85. J. Biol. Chem. 270: 19022-19027.

Gassmann, M., F. Casagranda, D. Orioli, H. Simon, C. Lai, R. Klein, and G. Lemke. 1995. A berrant neural and cardiac development in mice lacking the ErbB4 neuregulin receptor. Nature 378: 390-394.

Gautam, M., P.G. N oakes, J. Mudd, M. Nichol, G.C. Chu, J.R. Sanes, and J.P. M erlie. 1995. Failure of postsynaptic specialization to devel op at neuromuscular junctions of rapsyn-deficient mice. Nature 377: 232-236.

Gautam, M., P.G. N oakes, L. M oscoso, F. Rupp, R.H. Scheller, J.P. Merlie, and J.R. Sanes. 1996. Defective neuromuscular synaptogenesis in agrin-deficient mutant mice. Cell 85: 525535.

Gee, S.H., F. M ontanaro, M.H. Lindenbaum, and S. Carbonetto. 1994. Dystroglycan- $\alpha$, a dystrophin-associated glycoprotein, is a functional agrin receptor. Cell 77: 675-686.

Gesemann, M., A.J. Denzer, and M.A. Ruegg. 1995. Acetylcholine receptor-aggregating activity of agrin isoforms and mapping of the active site. J.Cell Biol. 128: 625-636.

Gillespie, S.K., S. Balasubramanian, E.T. Fung, and R.L. Huganir. 1996. Rapsyn clusters and activates the synapse-specific receptor tyrosine kinase MuSK. Neuron 16: 953-962.

Glass, D.J., D.C. Bowen, C. Radziejewski, J. Bruno, T.N. Stitt, T.E. Ryan, D.R. Gies, K. M attsson, S. Shah, S.J. Burden, D.M. Valenzuela, T.M. DeChiara, and G.D. Yancopoulos. 1996. Agrin acts via a M uSK receptor complex. Cell 85: 513-523.

Glass, D.J., E.D. A pel, S. Shah, D.C. Bowen, T.M. DeChiara, T.N. Stitt, J.R. Sanes, and G.D. Yancopoulos. 1997. Kinase domain of the muscle-specific receptor tyrosine kinase (MuSK) is sufficient for phosphorylation but not clustering of acetylcholine receptors: Required role for the MuSK ectodomain? Proc. Natl. Acad. Sci. 94: 8848-8853.

Godfrey, E.W., R.M. Nitkin, B.G. Wallace, L.L. Rubin, and U.J. M CM ahan. 1984. Components of Torpedo el ectric organ and muscle that cause aggregation of acetylcholine receptors on cultured muscle cells. J. Cell Biol. 99: 615-627.

Goldman, D., and J. Staple. 1989. Spatial and temporal expression of acetylcholine receptor mRN As in innervated and de nervated rat soleus muscle. Neuron 3: 219-228.

Goldman, D., B.M. Carlson, and J. Staple. 1991. Induction of adult-type nicotinic acetylcholine receptor gene expression in non-innervated regenerating muscle. Neuron 7: 649-658.

Goodearl, A.D., A.G. Yee, A.W. Sandrock, Jr., G. Corfas, and G.D. Fischbach. 1995. ARIA is concentrated in the synaptic basal lamina of the developing chick neuromuscular junction. J. Cell Biol. 130: 1423-1434.

Goodman, C.S. 1996. Mechanisms and molecules that control growth cone guidance. Annu. Rev. Neurosci. 19: 341-377.

Grady, R.M., H. Teng, M.C. Nichol, J.C. Cunningham, R.S. Wilkinson, and J.R. Sanes. 1997. Skeletal and cardiac myopathies in mice lacking utrophin and dystrophin: A model for Duchenne muscular dystrophy. Cell 90: 729-738.

Gramolini, A.O., C.L. Dennis, J.M. Tinsley, G.S. Robertson, J. Cartaud, K.E. Davies, and B.J. Jasmin. 1997. Local transcriptional control of utrophin expression at the neuromuscular synapse. J. Biol. Chem. 272: 8117-8120.

Gundersen K., J.R. Sanes, J.P. M erlie. 1993. N eural regulation of muscle acetylcholine receptor epsilon- and alpha-subunit gene promoters in transgenic mice. J. Cell Biol. 123: 15351544.

Guthrie, S. and A. Pini. 1995. Chemorepulsion of developing motor axons by the floor plate. Neuron 14: 1117-1130.

Hall, Z.W. and J.R. Sanes. 1993. Synaptic structure and devel- 
opment: The neuromuscular junction. (Suppl.) Cell/ Neuron 72/ 10: 99-121.

Hedgecock, E.M., J.G. Culottiand, D.H. Hall. 1990. The unc-5, unc- 6 and unc- 40 genes guide circumferential migrations of pioneer axons and mesodermal cells on the epidermis in $\mathrm{C}$. el egans. Neuron 2: 61-85.

Ho, W.H., M.P. Armanini, A. Nuijens, H.S. Phillips, and P.L. Osheroff. 1995. Sensory and motor neuron-derived factor. A novel heregulin variant highly expressed in sensory and motor neurons. J. Biol. Chem. 270: 14523-14532.

Hoch, W., M. Ferns, J.T. Campanelli, Z.W. Hall, and R. Scheller. 1993. Developmental regulation of highly active alternatively spliced forms of agrin. Neuron 11: 479-490.

Hoch, W., J.T. Campanelli, S. Harrison, and R.H. Scheller. 1994. Structural domains of agrin required for clustering of nicotinic acetylcholine receptors. EMBO J. 13: 2814-2821.

Holmes, W.E., M.X. Sliwkowski, R.W. Akita, W.J. Henzel, J. Lee, J.W. Park, D. Yansura, N. A badi, H. Raab, G.D. Lewis et al. 1992. Identification of heregulin, a specific activator of p185erbB2. Science 256: 1205-1210.

Imai zumi-Scherrer, T., D.M. Faust, J.C. Benichou, R. Hellio, and M.C. Weiss. 1996. Accumulation in fetal muscle and localization to the neuromuscular junction of CAMP dependent protein kinase $\mathrm{A}$ regulatory and catalytic subunits $\mathrm{RI}$ alpha and C alpha. J. Cell Biol. 134: 1241-1254.

Irie, M., M. Hata, K. Takeuchi, A. Ichtchenko, K. Toyoda, Y. Hirao, Takai, T.W. Rosahl, and T.C. Sudhof. 1997. Binding of neuroligins to PSD-95. Science 277: 1511-1515.

Jasmin, B.J., R.K. Lee, and R.L. Rotundo. 1993. Compartmentalization of acetylcholinesterase mRNA and enzyme at the vertebrate neuromuscular junction. Neuron 11: 467-477.

Jennings, C.G.B. and S.J. Burden. 1993. Development of the neuromuscular synapse. Curr. O pin. Neurobiol. 3: 75-81.

Jennings, C.G.B., S.M. Dyer, and S.J. Burden. 1993. M uscle-specific, trk-related receptor with a kringle domain defines a distinct class of receptor tyrosine kinases. Proc. Natl. Acad. Sci. 90: 2895-2899.

Jing, S., D. Wen, Y. Yu, P.L. Holst, Y. Luo, M. Fang, R. Tamir, L. Antonio, Z. Hu, R. Cupples, J.C. Louis, S. Hu, B.W. Altrock, and G.M .Fox. 1996. GDNF-induced activation of the ret protein tyrosine kinase is mediated by GDNFR- $\alpha$, a novel receptor for GDNF. Cell 85: 1113-1124.

Jo, S.A. and S.J. Burden. 1992. Synaptic basal Iamina contains a signal for synapse-specific transcription. Development 115: 673-680.

Jo, S.A., X. Zhu, M.A. M archionni, and S.J. Burden. 1995. NRGs are concentrated at nerve-muscle synapses and activate $A$ chreceptor gene expression. Nature 373: 158-161.

Jones G., A. Herczeg, M.A. Ruegg, M. Lichtsteiner, S. Kroger, H.R. Brenner. 1996. Substrate bound agrin induces expression of acetylcholine receptor epsilon-subunit gene in cultured mammalian muscle cells. Proc. Natl. Acad. Sci. 93: 5985-5990.

Jones, G., T. Meier, M. Lichtsteiner, V. Witzemann, B. Sakmann, and H.R. Brenner. 1997. Induction by agrin of ectopic and functional postsynaptic-like membrane in innervated muscle. Proc. Natl. Acad. Sci. 94: 2654-2659.

Klagsbrun, M. and A. Baird. 1991. A dual receptor system is required for basic fibroblast growth factor activity. Cell 67: 229-231.

Klarsfeld, A., J.L. Bessereau, A.M. Salmon, A. Triller, C. Babinet, and J.P. Changeux. 1991. An acetylcholine receptor $\alpha$-subunit promoter conferring preferential synaptic expression in muscle of transgenic mice. EMBO J. 10: 625-632.

Koike, S., L. Schaeffer, and J.P. Changeux. 1995. Identification of a DNA element determining synaptic expression of the mouse acetylchol ine receptor del ta-subunit gene. Proc. Natl. Acad. Sci. 92: 10624-10628.

Kornau, H.C., L.T. Schenker, M.B. Kennedy, and P.H. Seeburg. 1995. Domain interaction between NMDA receptor subunits and the postsynaptic density protein PSD-95. Science 269: 1737-1740.

Krueger N.X., D. Van Vactor, H.I. Wan, W.M. Gelbart, C.S. Goodman and H. Saito. 1996. The transmembrane tyrosine phosphatase DLAR controls motor axon guidance in Drosophila. Cell 84: 611-622.

Kuhse, J., H. Betz, and J. Kirsch. 1995. The inhibitory glycine receptor: Architecture, synaptic localization and molecular pathology of a postsynaptic ion-channel complex. Curr. Opin. Neurobiol. 5: 318-323.

Lahey, T., M. Gorczyca, X.X. Jia, and V. Budnik. 1994. The Drosophila tumor suppressor gene dl $g$ is required for normal synaptic bouton structure. Neuron 13: 823-835.

Lance-Jones, C. and M. Dias. 1991. The influence of presumptive limb connective tissue on motoneuron axon guidance. Dev. Biol. 143: 93-110.

Lance-Jones, C. and L. Landmesser. 1980. Motoneuron projection patterns in the chick hind limb following early partial spinal cord reversals. J. Physiol. 302: 581-602.

- - . 1981. Pathway selection by chick lumbrosacral motoneurons during normal development. Proc. R. Soc. London Ser. B 214: 1-18.

Landmesser, L. 1978. The devel opment of motor projection patterns in the chick hind limb. J. Physiol. 284: 391-414.

_-_. 1992. Growth cone guidance in the avian limb: a search for cellular and molecular mechanisms. In The nerve growth cone (ed. P.C. Letourneau, S.B. Kater, and E.R. Macagno), pp. 373-385. Raven Press, N ew York, NY.

Lee, K.F., H. Simon, H. Chen, B. Bates, M.C. Hung, and C. Hauser. 1995. Requirement for neuregulin receptor erbB2 in neural and cardiac development. Nature 378: 394-398.

Lewis, J., A. Chevalier, M. Kieny, and L. Wolpert. 1981. M uscle nerve branches do not develop in chick wings devoid of muscle. J. Embryol. Exp. Morphol. 64: 211-232.

Lin, D.M. and C.S. Goodman.1994. Ectopic and increased expression of Fasciclin II alters motoneuron growth cone guidance. Neuron 13: 507-523.

Loeb, J.A. and G.D. Fischbach. 1995. ARIA can be released from extracellular matrix through cleavage of a heparin-binding domain. J. Cell Biol. 130: 127-135.

Lopez-Casillas, F., S. Cheifetz, J. Doody, J.L. Andres, W.S. Lane, and J. M assagué. 1991. Structure and expression of the membrane proteoglycan betaglycan, a component of the TGF- $\beta$ receptor system. Cell 67: 785-795.

Marchionni, M.A., A.D. Goodearl, M.S. Chen, O. BerminghamMcDonogh, C. Kirk, M. Hendricks, F. Danehy, D. M isumi, J. Sudhalter, K. Kobayashi, et al. 1993. Glial growth factors are alternatively spliced erbB2 ligands expressed in the nervous system. Nature 362: 312-318.

Marte, B.M., D. Graus-Porta, M. Jeschke, F. Doriano, N.E. Nynes, and D. Taverna. 1995. NDF/heregulin activates MAP kinase and p70/p85 S6 kinase during proliferation or differentiation of mammary epithelial cells. Oncogene 10: 167-175.

Matsumura, K., J.M. Ervasti, K. Ohlendeick, S. Kahl, and K. Campbell. 1992. Association of dystrophin-related protein with dystrophin-associated proteins in $\mathrm{mdx}$ mouse muscle. Nature 360: 588-591.

Matthes, D.J., H. Sink, A.K.K. Kolodkin, and C.S. Goodman.1995. Semaphorin II can function as a selective inhibitor of specific synaptic arborizations. Cell 81: 631-639.

M CM ahan, U.J. 1990. The agrin hypothesis. Cold Spring Harbor 
Symp. Quant. Biol. 55: 407-418.

Meier, T., D.M. Hauser, M. Chiquet, L. Landmann, M.A. Ruegg, and H.R. Brenner. 1997. N eural agrin induces ectopic postsynaptic specializations in innervated muscle fibers. J. Neurosci. 17: 6534-6544.

Merlie, J.P. and J.R. Sanes. 1985. Concentration of acetylcholine receptor $\mathrm{mRNA}$ in synaptic regions of adult muscle fibers. Nature 317: 66-68.

Meyer, D. and C. Birchmeier. 1995. Multiple essential functions of neuregulin in development. Nature 378: 386-390.

Moscoso, L.M., J.P. M erlie, and J.R. Sanes. 1995a. N-CAM, 43krapsyn, and s-laminin $\mathrm{mRN} A \mathrm{~s}$ are concentrated at synaptic sites in muscle fibers. Mol. Cell. Neurosci. 6: 80-89.

M oscoso, L.M ., G.C. Chu, M. Gautam, P.G. N oakes, J.P. M erlie, and J.R. Sanes. 1995b. Synapse-associated expression of an acetylcholine receptor-inducing protein, ARIA/heregulin, and its putative receptors, ErbB2 and ErbB3, in developing mammalian muscle. Devel. Biol. 172: 158-169.

Niethammer, M., E. Kim, and M. Sheng. 1996. Interaction between the $C$ terminus of N MDA receptor subunits and multiple members of the PSD-95 family of membrane-associated guanylate kinases. J. Neurosci. 16: 2157-2163.

Nitkin, R.M., M.A. Smith, C. M agill, J.R. Fallon, Y.M. Yao, B.G. Wallace, and U.J. McM ahan.1987. Identification of agrin, a synaptic organizing protein from Torpedo electric organ. J. Cell Biol. 105: 2471-2478.

Noakes, P.G., W.D. Phillips, T.A. Hanley, J.R. Sanes, and J.P. Merlie. 1993. 43K protein and acetylcholine receptors colocalize during the initial stages of neuromuscular synapse formation in vivo. Dev. Biol. 155: 275-280.

N omura, A., R. Shigemoto, Y. Kakamura, N. Okamoto, N. M izuno, and S. Nakanishi. 1994. Developmentally regulated postsynaptic local ization of a metabotropic gl utamate receptor in rat bipolar cells. Cell 77: 361-369.

N ose, A., V.B. M ahajan, and C.S. Goodman. 1992. Connectin: A homophilic cell adhesion molecule expressed on a subset of muscle and the motoneurons that innervate them in Drosophila. Cell 70: 553-567.

Ohlendieck, K., J.M . Ervasti, K. M atsumura, S.D. Kahl, C.J. Leveille, and K.P. Campbell. 1991. Dystrophin-related protein is localized to neuromuscular junctions of adult skeletal muscle. Neuron 7: 499-508.

Peles, E. and Y. Yarden. 1993. Neu and its ligands: from an oncogene to neural factors. Bioessays 15: 815-824.

Phillips, W.D. and J.P. Merlie. 1992. Recombinant neuromuscular synapses. BioEssays 14: 671-679.

Phillips, W.D., C. Kopta, P. Blount, P.D. Gardner, J.H. Steinbach, and J.P. Merlie. 1991. ACh receptor-rich membrane domains organized in fibroblasts by recombinant 43-kilodalton protein. Science 251: 568-570.

Qu, Z. and R.L. Huganir. 1994. Comparison of innervation and agrin-induced tyrosine phosphorylation of the nicotinic acetylcholine receptor. J. Neurosci. 14: 6834-6841.

Rapraeger, A.C., A. Krufka, and B.B. Olwin. 1991. Requirement of heparan sulfate for bFGF mediated fibroblast growth and myoblast differentiation. Science 252: 1705-1708.

Reist, N.E., M.J. Werle, and U.J. M cM ahan. 1992. A grin released by motor neurons induces the aggregation of acetylcholine receptors at neuromuscular junctions. Neuron 8: 865-868.

Riethmacher, D., E. Sonnenberg-Riethmacher, V. Brinkman, T. Yamaai, G.R. Lewin, and C. Birchmeier. 1997. Severe neuropathies in mice with targeted mutations of the erbB3 receptor. Nature 389: 725-729.

Ring, C., H. Hassell, and W. Halfter. 1996. Expression pattern of collagen IX and potential role in the segmentation of the peripheral nervous system. Dev. Biol. 180: 41-53.
Ruegg, M.A., K.W.K. Tsim, S.E. Horton, S. Kröger, G. Escher, E.M. Gensch, and U.J. M cM ahan. 1992. The agrin gene codes for a family of basal lamina proteins that differ in function and distribution. Neuron 8: 691-699.

Sandrock, A.W., S.E. Dryer, K.M. Rosen, S.N. Gozani, R. Kramer, L.E. Theil, and G.D. Fischbach. 1997. Maintenance of acetylcholine receptor number by neuregulins at the neuromuscular junction in vivo. Science 276: 599-603.

Sanes, J.R., Y.R. Johnson, P.T. Kotzbauer, J. Mudd, T. Hanley, J.C. Martinou, and J.P. M erlie. 1991. Sel ective expression of an acetylcholine receptor-lac $Z$ transgene in synaptic nuclei of adult muscle fibers. Development 113: 1181-1191.

Sanes, J.R., L.M. Marshall, and U.J. M cMahan. 1978. Reinnervation of muscle fiber basal lamina by after removal of myofibers. Differentiation of regenerating axons at original synaptic sites. J. Cell Biol. 78: 176-198.

Shepherd, I., Y. Luo, J.A. Raper, and S. Chang. 1996. The distribution of collapsin-1 mRN A in the developing chick nervous system. Dev. Biol. 173: 185-199.

Simon, A.M., P. Hoppe, and S.J. Burden. 1992. Spatial restriction of AChR gene expression to subsynaptic nuclei. Development 114: 545-553.

Si, J., Z. Luo, and L. Mei. 1996. Induction of acetylcholine receptor gene expression by ARIA requires activation of mitogen-activated protein kinase. J. Biol. Chem. 271: 1975219759.

Soltoff, S.P., K.L. Carraway, S.A. Prigent, W.G. Gullick, and L.C. Cantley. 1994. ErbB3 is involved in activation of phosphatidylinositol 3-kinase by epidermal growth factor. Mol. Cell Biol. 14: 3550-3558.

Son, Y.J. and W.J. Thompson. 1995. N erve sprouting in muscle is induced and guided by processes extended by Schwann cells. Neuron 14: 133-141.

Sugiyama, J., D.C. Bowen, and Z.W. Hall. 1994. Dystroglycan binds nerve and muscle agrin. Neuron 13: 103-115.

Sugiyama, J., D.J. Glass, G.D. Yancopoulos, and Z.W. Hall. 1997. Laminin induced acetylchol ine receptor clustering: An alternative pathway. J. Cell Biol. 139: 181-191.

Tanabe, Y. and T.M. Jessell. 1996. Diversity and pattern in the devel oping spinal cord. Science 274: 1115-1123.

Tang, J., S.A. Jo, and S.J. Burden. 1994. Separate pathways for synapse-specific and electrical activity-dependent gene expression in skeletal muscle. Development 120: 1799-1804.

Tansey, M.G., G.C. Chu, and J.P. Merlie. 1996. ARIA/HRG regulates $A C h R \in$ subunit gene expression at the neuromuscular synapse via activation of phosphatidylinositol 3-kinase and Ras/MAPK pathway. J. Cell Biol. 134: 465-476.

Tessier-Lavigne, M. and C.S. Goodman. 1996. The molecular biology of axon guidance. Science 274: 1123-1133.

Trachtenberg, J.T. and W.J. Thompson. 1997. Nerve terminal withdrawl from rat neuromuscular junctions induced by neuregulin and Schwann cells. J. Neurosci. 17: 6243-6255.

Tsuchida, T., M. Ensini, S.B. M orton, M. Baldassare, T. Edlund, T.M. Jessell, and S.L. Pfaff. 1994. Topographic organization of embryonic motor neurons defined by expression of LIM homeobox genes. Cell 79: 957-970.

Valenzuela, D.M., T.N. Stitt, P.S. DiStefano, E. Rojas, K. M attsson, D.L. Compton, L. Lunez, J.S. Park, J.L.Stark, D.R. Gies, S. Thomas, N.G. Copeland, N.A. Jenkins, S.J. Burden, D.J. Glass, and G.D. Yancopoulos. 1995. Identification of a receptor tyrosine kinase specific for the skeletal muscle lineage: expression in embryonic muscle, at the neuromuscular junction and after injury. Neuron 15: 573-584.

Wallace, B.G. 1994. Staurosporine inhibits agrin-induced acetylcholine receptor phosphorylation and aggregation. J. Cell Biol. 125: 661-668. 
Burden

Wallace, B.G., Z. Qu, and R.L. Huganir. 1991. Agrin induces phosphorylation of the nicotinic acetylcholine receptor. Neuron 6: 869-878.

Wang, H.U. and D.J. Anderson. 1997. Eph family transmembrane ligands can mediate repulsive gui dance of trunk neural crest migration and motor axon outgrowth. Neuron 18: 383396.

Wen, D., E. Peles, R. Cupples, S.V. Suggs, S.S. Bacus, Y. Luo, G. Trail, S. Hu, S.M. Silbiger, R.B. Levy et al. 1992. N eu differentiation factor: A transmembrane glycoprotein containing an EGF domain and an immunogl obulin homology unit. Cell 69: 559-572.

Yang, S.H., P.F. Armson, J. Cha, and W.D. Phillips. 1997. Clustering of GABAA receptors by rapsyn/43kD protein in vitro. Mol. Cell. Neurosci. 8: 430-438.

Zhu, X., C. Lai, S. Thomas, and S.J. Burden. 1995. N euregulin receptors, erbB3 and erbB4, are localized at neuromuscular synapses. EMBO J. 14: 5842-5848. 


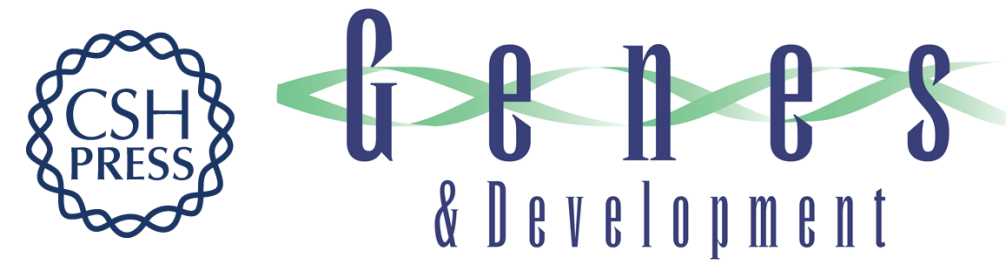

\section{The formation of neuromuscular synapses}

Steven J. Burden

Genes Dev. 1998, 12:

Access the most recent version at doi:10.1101/gad.12.2.133

References This article cites 144 articles, 54 of which can be accessed free at: http://genesdev.cshlp.org/content/12/2/133.full.html\#ref-list-1

License

Email Alerting Receive free email alerts when new articles cite this article - sign up in the box at the top Service right corner of the article or click here.

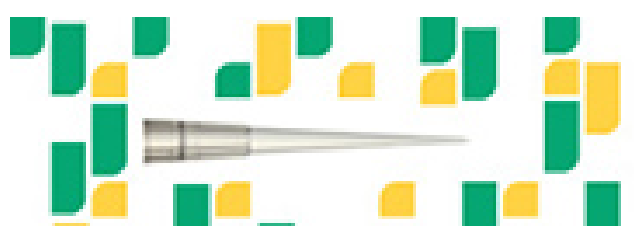

Focused on your science. 